\title{
Reconsidering Politics as a Man's World: Images of Male Political Leaders in France and Norway
}

\author{
Anne Krogstad and Aagoth Storvik
}

Researchers have often pointed to the masculine norms that are integrated into politics. This article explores these norms by studying male images of politics and power in France and Norway from 1945 to 2009. Both dress codes and more general leadership styles are discussed. The article shows changes in political aesthetics in both countries since the Second World War. The most radical break is seen in the way Norwegian male politicians present themselves. The traditional Norwegian leadership ethos of piety, moderation, and inward orientation is still important, but it is not as selfeffacing and inelegant as it used to be. However, compared to the leaders in French politics, who still live up to a heroic leadership ideal marked by effortless superiority and seduction, the Norwegian leaders look modest. To explain the differences in political self-presentation and evaluation we argue that cultural repertoires are not only national constructions but also gendered constructions.

Keywords: photographs; politics; aesthetics; gender; national cultural repertoires 
When people think of presidents and prime ministers, they usually think of the incumbents of these offices. ${ }^{1}$ In both France and Norway, these incumbents have, with the exception of Prime Minister Edith Cresson in France and Prime Minister Gro Harlem Brundtland in Norway, been male (and white). Researchers have often pointed to the masculine norms which are integrated into the expectations of what political officeholders should look like and be. Politics, it is claimed, is still very much a man's world. ${ }^{2}$ However, maleness does not express general political leadership in a simple and undifferentiated way. In this article we explore this variety by studying the male images of politics and power in France and Norway from 1945 to 2009. More specifically we compare public photographs of high-level politicians--from Charles de Gaulle to Nicolas Sarkozy in France and from Einar Gerhardsen to Jens Stoltenberg in Norway--to see how they portray themselves and their governments and how they are portrayed by photographers. Our main focus is on formal clothing, particularly the male suit. This nonuniform uniform, as Rubinstein ${ }^{3}$ calls it, is commonly regarded as closely identified with maleness. It can also be seen as a requisite of power. In addition to the study of the suit, we include examples of politicians' more informal clothing. How are these aesthetical performances expressed and commented upon by journalists and other writers in the two countries? The aim is to identify forms of gendered aesthetical presentations, how they express ideas about male political leadership, how they can be contextualized within national and cultural repertoires, and how they have changed.

\section{Images, National Cultural Repertoires, and Gender}

Because we deal with images of male politicians in a field permeated by masculine--and partly taken for granted--associations, we should think twice about the act of seeing. While texts are based on argumentation, images are based on association, the associations that

\footnotetext{
${ }^{1}$ R. Murray, “Gendered Leadership in the Fifth Republic,” paper presented at the Colloquium on Political Leadership in France, Maison Française, Oxford, UK, 2 May 2009.

${ }^{2}$ E. Ibrocheva and M. Raicheva-Stover, "Engendering Transition: Portrayals of Female Politicians in the Bulgarian Press,“ Howard Journal of Communications 20 (2009): 11-128.

${ }^{3}$ R. Rubinstein, Dress Codes (Oxford, UK, 2001), 86.
} 
spontaneously pop up in the beholders' minds. ${ }^{4}$ Pictures, images, give an intuitive sense of presence, a momentary explosion of meaning. In this way they can have an effect even before the viewer is conscious of it. ${ }^{5}$ While many researchers have subsumed visual communication under reading terms (“reading images”), Müller proposes a less language-oriented view by claiming that "images are not read, they are seen." 6 This is admittedly a subtle difference, but it may have consequences in the study of naturalized perceptions and attitudes. Müller further maintains that the rules that apply to visual meaning creation "are less standardized and more context-dependent than the meaning created and communicated in the textual mode."7 This context is perhaps most easy to reveal in comparative studies.

In the analysis of the French and Norwegian contexts we draw on the concept “national cultural repertoires.” Ann Swidler introduced the term “cultural repertoires” in order to study culture's role in shaping interpretation and action. ${ }^{8}$ Lamont and Thévenot elaborated the term for comparative purposes, using the term "national cultural repertoires of evaluation.”9 These repertoires of evaluation consist of sets of tools in the form of frames of interpretation and strategies of legitimization employed within specific national contexts. They are deemed "to be available across situations and to pre-exist individuals, although also transformed and made salient by individuals." ${ }^{10}$ We use this perspective in studying the aestheticized national and cultural repertoires of politics in France and Norway. This is somewhat different from the way it has been used earlier. Swidler and Lamont and Thévenot study the use of verbal strategies. In the present case we focus on political repertoires that are both verbal and nonverbal: visual portrayals and biographical/journalistic characterizations of politicians' aesthetical performances.

While national cultural repertoires can be seen as a framework for studying the macro level of politics, Erving Goffman provides us with an analytical gaze and a conceptual tool kit for studying the micro levels of politics. ${ }^{11}$ Here we will use his writings on the presentation of self, with the accompanying concept of impression management and the stage. Goffman shows how individuals change behavior according to a mosaic of varying contexts, or

\footnotetext{
${ }^{4}$ M. G. Müller, "What Is Visual Communication? Past and Future of an Emerging Field of Communication Research,” Studies in Communication Sciences 7/2 (2007): 13.

${ }^{5}$ H. Read, The Meaning of Art (1931; Baltimore, 1967), 51.

${ }^{6}$ Müller, "What Is Visual Communication?” 9.

${ }^{7}$ Ibid., 13.

${ }^{8}$ A. Swidler, “Culture in Action: Symbols and Strategies," American Sociological Review 51, no. 2 (1986): 273-86.

${ }^{9}$ M. Lamont and L. Thévenot, ed., Rethinking Comparative Cultural Sociology (Cambridge, UK, 2000).

${ }^{10}$ Ibid., 5-6.

${ }^{11}$ E. Goffman, The Presentation of Self in Everyday Life (Harmondsworth, UK, 1959).
} 
“definitions of the situation.” He also employs the concept “frame,” which can be seen as a collectivity of “definitions of situations” that together govern social events and people’s involvement in them. The term "frame" not only connects to national and cultural repertoires. It has also been used in mass communication research to study journalists' decisions about how to present an issue--and what information to include or exclude from their stories. ${ }^{12}$ Goffman's main point is that people in everyday life present themselves in ways to influence others. We will add that political leaders do so, too, and even more strategically than most people. Goffman looks at action and interaction from a theatrical point of view, meaning that action and interaction are seen as staged performances that are composed to give a certain impression, most likely a favorable one. Facial expressions, gestures, and clothes constitute the personal front, and objects and people in the immediate surroundings are combined into what he calls “the stage.” And being a top politician seems to have much to do with being visible as a person performing a role on a political stage.

While Goffman writes about presentations of self and role performance, he also develops the concepts of role embracement and role distance. Role embracement refers to those roles whose "virtual self” people freely adopt. ${ }^{13}$ Role distance concerns intentional actions that convey some "detachment of the performer" from the role he or she is performing. ${ }^{14}$ This means that a person's identity is not reducible to his or her official role. Role distance therefore concerns being and not being at the same time. It can be created in many ways, for example by playing another role that somewhat contradicts one's official role or by overdoing one's official role. Visually role distance can be conveyed through wearing clothes typical for one identity while showing gestures or saying words indicating another identity.

Likewise, the different types of masculinities we see among French and Norwegian politicians can be both contradictory to each other and in themselves. As Collinson and Hearn suggest, forms of masculinity vary in specific situations, in different historical times, and in various cultural milieus. ${ }^{15}$ Different forms of masculinity might also be hierarchically ordered, and in relation to this Connell speaks about hegemonic masculinities, the most socially endorsed form of masculinity. ${ }^{16}$ He argues that management and leadership are the most clear-cut form of hegemonic masculinity. While a leadership position implies the right

\footnotetext{
${ }^{12}$ G. Tuchmann, Making the News: A Study in the Construction of Reality (New York, 1978).

${ }^{13}$ P. Manning, Erving Goffman and Modern Sociology (Stanford, CA, 1992).

${ }^{14}$ E. Goffman, Encounters: Two Studies in the Sociology of Interaction (Indianapolis, IN, 1961), 110.

${ }^{15}$ D. L. Collinson and J. Hearn, ed., Men as Managers, Managers as Men: Critical Perspectives on Men, Masculinities and Managements (London, 1996), 10.

${ }^{16}$ R. W. Connell, Masculinities, 2nd ed. (1987; Cambridge, UK, 2005).
} 
to exert power over subordinates, a hegemonic masculinity often appears to be a necessary prerequisite to attain such a position. Leadership and hegemonic masculinity are closely connected, and this is also the case with power, masculinity, and sexuality. Here we are inspired by Bourdieu, who argues that the combination of power and sexuality enforce each other for men. ${ }^{17}$ We will try to untangle some of these relations.

\section{Data and Methods}

We have chosen to compare Norway and France for both their similarities and differences. Both are modern Western countries, with highly developed welfare states and rather large public sectors. The political party formations, with the left-right divide, share certain fundamental commonalities. ${ }^{18}$ But there are also striking differences. In its elitism and strong hierarchy French society is clearly different from the relatively egalitarian Norwegian society. In addition, gender relations are perceived and expressed differently in the two societies.

Since the two countries in many ways are such an unlikely pair for comparison, the approach chosen in this study may be termed "contextual and reflexive” rather than "comparative" in the strict sense of the word. ${ }^{19}$ The aim is to gain an understanding of preconditions and options for aesthetical self-presentations and portrayals in politics. The method is inspired by an approach that anchors the evaluation of politicians' self-presentation in what, broadly seen, seems to be acceptable or unacceptable within the two nations. ${ }^{20}$ Cases that challenge people's views on political image building will be of interest, not least because they occasionally reveal where the borders between legitimate and illegitimate portrayals are drawn.

In studying national cultural repertoires of leadership, the leaders of political parties appear to be an excellent choice to focus on. In contrast to other leaders they are elected and therefore they must somehow appeal to broad segments of a country's population. The empirical study includes male top politicians, i.e., presidents (in France) and prime ministers (in both France and Norway). The leaders selected for study served between 1945 and 2009.

\footnotetext{
${ }^{17}$ P. Bourdieu, Masculine Domination (Stanford: CA, 2001).

${ }^{18}$ H. Baldersheim and J.-P. Daloz, eds., Political Leadership in a Global Age: The Experiences of France and Norway (Aldershot, UK, 2003).

${ }^{19}$ Ibid.

${ }^{20}$ J.-P. Daloz, “The Guises of Political Representation,” in Culture Troubles: Politics and the Interpretation of Meaning, ed. P. Chabal and J.-P. Daloz, (London, 2006), 269-308.
} 
We have focused on the most prominent ones. Politicians who were in these leadership positions briefly are not described, unless they seemed to add something new from a cultural and aesthetical perspective. We try to capture both the ordinary and the extraordinary aesthetical presentations.

As mentioned, we have two main sources of data: (1) pictures of male politicians, and (2) written characterizations of male politicians' personal appearance, for instance journalists' words and comments about them. The portrayals of political leaders are collected from a large body of texts. For the period from 1945 to 2000 we base the analysis on descriptions and political biographies produced by journalists and writers. For the period 2000-2009 we have collected material (newspapers, magazines, journals) using a systematic library/Internet search. These diverse materials are sources that ordinary people use to form their opinions about politicians.

The personal characterizations refer first of all to descriptions of appearance, but we also have included inner characterizations that may have a relationship to outward appearance--such as charming, modest, with inner strength, powerful, seductive, solemn, mystical. We have tried to collect characterizations that are typical for the politician in question. By typical we here mean characterizations that are repeated by different sources. When there are different opinions we have relied on the version that is most cited.

In order to evaluate how politicians merge or separate their official political roles with their other roles, we have chosen photographs that are taken both in formal political settings and in more informal settings in the politicians' leisure time. In other words we are trying to capture a wide range of self-presentations and portrayals rather than just one type. The journalistic descriptions of the politicians' visual performances are chosen in the same way as the pictures; we have looked both for what may be termed "typical characterizations" and for more unusual descriptions. We thereby attempt to identify both the core and the range of the national and cultural repertoires of evaluation.

\section{France: Grandeur, Effortless Superiority, and Elegance}

According to historians specializing in European monarchies, nowhere else in Europe were the gaps between the top and the bottom of society as visible as in ancien régime France. In spite of France's being the origin of the bourgeois revolution, the country is still known for-- 
and affected by--Louis XIV's Versailles. ${ }^{21}$ Issues of privilege and signs of social differentiation have been a constant obsession. ${ }^{22}$ The grandeur of French political leaders is not surprising considering that France is imbued with the heritage of a Great Power tradition, unlike Norway. Also, in the realm of culture and ideas, France has been an exporter of political inventions and cultural models. ${ }^{23}$ In politics, we often find a leadership style that we have termed "effortless superiority." ${ }^{24}$ But how is this grandeur and superiority linked to what we often regard as masculinity? We will focus on dimensions such as military experience, remoteness/closeness, and gallantry.

France has had many great leaders, but in the postwar period General Charles de Gaulle (president 1959-69) was the greatest. He was predominantly seen as charismatic and an inspiration for later French politicians. As many of the pictures of him illustrate, his grandeur was accentuated by uniforms, medals, and large gestures. His posture was always formal and his facial expressions were grave. The uniform and medals created an image of a courageous war hero and, together with his large gestures, an impression of drama. According to de Gaulle a leader should not appear as an ordinary man, but rather be somewhat withdrawn so that an impression of mystique or surprise is created. De Gaulle himself was in fact never viewed as ordinary, as one of the masses. ${ }^{25}$ He formulated his insights on political persuasion this way: “One does not move crowds without elementary feeling, violent images and brutal invocations.”26

\section{[Picture 1 approx. here]}

All subsequent French top politicians have had to relate themselves to de Gaulle's leadership image of grandeur. His masculinity to a large degree rested on the prevailing relationship that through most recorded history has existed between the warrior role and traditional perceptions of manhood, the military serving as a main agent in awarding men the core qualities deemed necessary in order to be seen as "real men.”27 This strong link between

\footnotetext{
21 J.-P. Daloz, "Between Majesty and Proximity: The Enduring Ambiguities of Political Representation in France,” French Politics 6/3 (2008): 302-320.

${ }^{22}$ O. Hufton, Europe: Privilege and Protest, 1730-1789 (Oxford, UK, 2000).

${ }^{23}$ H. Baldersheim and J.-P. Daloz, ed., Political Leadership in a Global Age.

${ }^{24}$ A. Krogstad and A. Storvik, "Seductive Heroes and Ordinary Human Beings: Charismatic Political Leadership in France and Norway," Comparative Social Research 23 (2007), 211-45.

${ }^{25}$ H. Drake and J. Gaffney, The Language of Leadership in Contemporary France (Aldershot, UK, 1996).

${ }^{26}$ J. K. Chalaby, The de Gaulle Presidency and the Media: Statism and Public Communications (Basingstoke, UK, 2002), 169.

${ }^{27}$ J. B. Elsthain, Women and War (New York, 1987).
} 
masculinity and warfare is less visible in de Gaulle’s successors, but heroism and courage still remain central. By ritual and symbols Pompidou (president 1969-74), Giscard d'Estaing (1974-81), Mitterrand (1981-95), Chirac (1995-2007), and Sarkozy (2007-) all have employed the heroic charisma that de Gaulle added to the position. But the often-found remoteness of the heroic man has changed somewhat.

Georges Pompidou (Gaullist) had all the constitutional tools and symbols his predecessor had but did not always succeed in living up to the public's expectations. Photos of him show a man with a more low-key style than de Gaulle. In some pictures we see that he uses medals and other types of military-order ribbons, but he does not appear in uniform. Pompidou wanted to demystify the presidency and show that he was an ordinary man identifying with the people. For example, he let photographers take pictures of him and his family and friends at informal gatherings. In some ways Pompidou succeeded in demystifying the presidency, but his effort to identify with the people more or less failed. ${ }^{28}$ A reason for this was that he appeared as an eloquent cosmopolitan intellectual. ${ }^{29}$ He was described as a prince of finance whose suits seemed to be made by the best tailors in Paris, an image far from an ordinary man.

Valéry Giscard d'Estaing (center right), Pompidou's successor, also let himself be photographed in informal settings, for example, sitting behind his desk in an ordinary pullover and participating in cross-country skiing competitions. With his good looks, elegant appearance, and aristocratic background, he gave the presidency a natural glamour. Whether this might be seen as masculine leadership is an interesting question. A culturally sophisticated leadership image of this type might also connote feminine qualities. But as Bourdieu reminds us, men with high cultural capital can display feminine qualities without being punished for it, at least within the French national and cultural repertoire. ${ }^{30}$

The elitism of the three presidents mentioned above had created a social barrier. During the 1980s and 1990s it became clear that French politicians had to be both visionary, superior, and presidential, on the one hand, and on the other ordinary and close to the people, ${ }^{31}$ a rather tall order.

François Mitterrand (Socialist Party) was elected president on a program that openly rejected the Gaullist style, a program of change and democratization. However, only a few months after taking office, he began behaving in ways that resembled de Gaulle. He was

\footnotetext{
${ }^{28}$ W. Safran, The French Polity (New York, 1985), 154.

29 S. Aurén, Georges Pompidou: de Gaulles efterträdare (Stockholm, 1969), 148.

${ }^{30}$ Bourdieu, Masculine Domination.

${ }^{31}$ Drake and Gaffney, The Language of Leadership in Contemporary France.
} 
variously called monarch, patriarch (uncle/father), and sphinx. The combination of power and mystique created a basis for his charisma. His visual appearance was clearly different from de Gaulle’s. Journalists described him as a man who projected the image of an “attractive, dynamic, intelligent, professionally well-trained expert.”32 During several presidential elections Mitterrand got help from Jacques Séguéla, founder and creative director of one of the largest advertising agencies in France at the time. Mitterrand was portrayed as calm, brave, and patriotic. In a 1976 picture at a beach we see his relaxed self-presentation in informal leisure wear, a self-presentation based on the advice of Séguéla. This picture seems to portray him as a numinous man with inner strength..

Chirac (conservative/Union for a Popular Movement [UMP]) made grandeur, bravery, passion, and will into his trademarks. Both personal and bodily characteristics seemed to add to his charisma. Early in his political career, he had a confrontational, almost aggressive style, a style often associated with masculinity. However his media strategist, Thierry Saussez, leader of Images et Strategies, contributed to change the image of Chirac from a cold and calculating one to one that was softer, and also vaguely sexy and sensitive. In his elegant suits from Guy Laroche, Chirac was portrayed as a modern statesman. Toward the end of his presidency, however, Chirac was increasingly portrayed as old and politically weak. ${ }^{33}$ Nevertheless, he was still a master of gallantry. A famous photo from 2005 shows him kissing the newly appointed German chancellor Angela Merkel's hand in an almost aristocratic manner. Chirac seems to have lacked a suitable image for a president's leisure wear, however. A picture shows him walking in the woods with his wife and grandchild. Also in this context his clothing is very formal, almost odd, and perhaps a part of a conscious photo opportunity. Nicolas Sarkozy (conservative/UMP) appears more like a hardworking professional businessman than an aristocrat. He represents something relatively new in French postwar politics. Admittedly Sarkozy has a bourgeois, even aristocratic background. But he also has an immigrant background: his father was a Hungarian aristocrat, his mother was Greek. Like his predecessor, Chirac, Sarkozy wears elegant suits. With his lack of height the impression created is not the same, something that he has tried to hide by wearing shoes with thick soles, or by arranging photo opportunities with persons who are not too tall. Sarkozy has not hidden the fact that he has fought hard to enter top-level politics. As he once said: "I fought for everything I have.” He is described as "having a twitchy all-elbows manner and no one would

\footnotetext{
${ }^{32}$ S. Bauman-Reynolds, Francois Mitterrand: The Making of a Socialist Prince in Republican France (Westport, CT, 1995), 171.

${ }^{33}$ Marianne, 14 January 2006.
} 
call him warm or easygoing.” ${ }^{34}$ Even his body language shows some of these traits. He often points at his audience in a rather intense and belligerent way. Sarkozy is an example not of a matter-of-fact authority, but rather of superiority with effort. Can this be said about his form of masculinity too?

\section{[Picture 2 approx. here]}

Sarkozy is often referred to as a "seducer." ${ }^{35}$ After he won the presidential election in 2007, we saw holiday pictures of him in Egypt with his new girlfriend, the Italian-born Carla Bruni, who four months after his divorce would become his third wife. In the pictures they are in leisure wear; Sarkozy is dressed in jeans and what looks like an army shirt, and he is wearing pilot sunglasses. This is a cool mystical look, and one that refers to masculine film heroes. Bruni adds youth, beauty, and glamour to Sarkozy’s image, not least because of her status as a singer and former photo model, a reminder of how the national cultural repertoire is supplemented by the international celebrity field. She also gives him an image of virility. The image of an attractive man is being supported by the phrase used for his female ministers: "Sarkozy’s cabinet of sirens." 36

\section{Norway: Conspicuous Modesty}

There are certain differences in the challenges to those in political leadership positions in small countries in contrast to world powers. Weber argues that any numerically "large" nation is confronted by tasks of a quite different order from those devolving on other nations "such as the Swiss, the Danes, the Dutch or the Norwegians." ${ }^{37}$ By this he means that peoples that are "small” in numbers and in terms of power "have different obligations and therefore other cultural possibilities.” ${ }^{38}$ Our assumption is that these differences are reflected in political leadership styles, and most likely also in expressions of masculinity.

\footnotetext{
${ }^{34}$ The Atlantic Monthly, September 2005.

${ }^{35}$ Paris Match, 5 March 2008.

${ }^{36}$ Mail Online, 12 March 2008.

${ }^{37}$ M. Weber, Political Writings, ed. P. Lassman and R. Speirs, Cambridge Texts in the History of Political Thought (Cambridge, UK, 1994), 75 (our italics).

${ }^{38}$ Ibid.
} 
While most of the French politicians we have discussed seem to have exemplified grandeur, elegance, and superiority, Norwegian politics, on the other hand, is characterized by what Daloz has called "conspicuous modesty." 39 "The informal rules that discourage feelings of superiority can be felt among most members of the elite, but these rules are even more powerful when it comes to politicians, who cannot be seen to ignore their application,” he claims. ${ }^{40}$ Equality and sameness are basic goals that sum up the Norwegian political ideal. This ideal contains great rhetorical power. In politics, where politicians are dependent on voter support, it is important not to be full of oneself; rather, it is important to appear modest and low-key--at the same time that one is leading. Daloz points to various cultural and ideological explanations such as "mentalities [...], the traditional figure of the independent peasant, the influence of Lutheranism and its moral code of austerity [...] or to the social democratic hegemony." ${ }^{41}$ We will also point out the influence of a movement that started in the early 1800s where Norwegian rural communities were idealized at the expense of the more European-oriented academic elites in the big cities. ${ }^{42}$ How are these national and cultural experiences reflected in the looks of their male political leaders? Is the hegemonic masculinity linked to this modest and equality-oriented leadership ideal expressed and commented upon differently compared to what we see in France?

Like de Gaulle, Einar Gerhardsen, Norway’s prime minister in several periods during the 1940s, 1950s, and 1960s, was tall and lean, but there the parallels stop. Gerhardsen had no education and was a road worker before he entered politics and became the leader of the Norwegian Labour Party. Pictures show him wearing suits that do not really fit him. A picture of him with one of his governments shows that this was also the case with many of his ministers. The suits were often too small or too big, the sleeves were not long enough or the material creased. Another picture shows Gerhardsen walking with his wife in the mountains. Their clothes are simple and inexpensive sportswear, and the surroundings indicate that they are outdoorsy and love nature, which may be seen as Norwegian core values. The modesty that Gerhardsen's clothes signal is also reflected in his general lifestyle. Gerhardsen lived all his life in a rather modest apartment in a working-class area in eastern Oslo. The apartment, which one gets a glimpse of in some pictures, is simple but modern.

\footnotetext{
${ }^{39}$ J.-P. Daloz, "Political Elites and Conspicuous Modesty: Norway, Sweden, Finland in Comparative Perspective,” Comparative Social Research 23 (Oxford, UK, 2007), 173-212.

40 J.-P. Daloz, "How Political Representatives Gain Legitimacy: Symbolic Perspectives,» in International Social Science Journal 197 (special issue on Legitimacy) (2009):293.

41 J.-P. Daloz, "How Political Representatives Gain Legitimacy: Symbolic Perspectives,» in International Social Science Journal 197 (special issue on Legitimacy) (2009):293.

${ }^{42}$ R. Slagstad, De nasjonale strateger (Oslo, 1998).
} 
The appearance and lifestyle of Gerhardsen, who was the architect behind the Norwegian welfare state, supports the image of Norway as strongly characterized by a special type of power, which Henningsen and Vike term “ordinary people’s power.” 43 But ordinary people also have gender: Referring to Gerhardsen as "the father of the country” connotes more than a family-oriented man. At this national level it connotes a special type of male protector, which implicitly relegates the people to a dependent, almost feminized position, reliant on a man for safekeeping.

\section{[Picture 3 approx. here]}

Let us move on to the appearance of another prime minister, Per Borten (PM 196571), who was the leader of the Centre Party. A 1971 picture of Borten taken at the Parliament shows him in a very formal suit. However, his jacket appears too short for his body. Another picture shows him in his leisure-time home, a farm. He is driving his tractor in a checkered shirt--a shirt that at least in Norway strongly symbolizes manual work. Since farming has historically been regarded as a legitimate recruitment basis for political leaders, this is not an unusual picture. A more astonishing picture from 1969 shows Borten in his underwear only, working at his farm. This is actually not an “out of character situation” (Goffman 1959); this is the way Borten welcomed a journalist and a photographer at his farm three days before he was to receive the British queen. The picture created a great deal of amusement, but it did not really damage his reputation. After all, it only showed that he was an ordinary human being and therefore very much in line with the Norwegian political ethos.

Kåre Willoch (PM 1981-86), prime minister from the Conservative Party, was--in contrast to most post-World War II prime ministers--an educated man, a social economist; in many ways he was not a typical Norwegian political leader. His suits were usually more elegant than the suits of earlier prime ministers. In addition Willoch was known for his distinguished speech and rhetorical strength. In a picture taken of him in his leisure time we see that nevertheless he also knew how to make the Norwegian ethos work for him. We see him at his cottage doing the dishes. He is dressed in a plain lumberjack shirt, again a sign of manual work. The cottage itself can be understood as a sign of love for nature and simple country life. However, working-class people could seldom afford to have cottages then; thus,

\footnotetext{
${ }^{43}$ E. Henningsen and H. Vike, "Folkelig elitisme? Om offentlighetens kultur i Norge,” Norsk antropologisk tidsskrift 10 (1999): 150-67.
} 
what we see here is an upper-middle-class version of love for nature and simplicity. That Willoch let himself be portrayed doing the dishes exemplifies a role expansion; it is a sort of manual work, but in this case it is domestic work usually regarded as female work--being performed by a highly educated male Conservative prime minister. Since this picture was taken in 1985, it could be read as a portrayal of Willoch's being supportive of issues of gender equality, which had become a hot political issue at the time, put forward not least by his main political opponent, the Labour Party’s Gro Harlem Brundtland.

Norway's first and only female prime minister, often termed "the mother of the nation,” changed the aesthetics of Norwegian government. After Brundtland the prime ministers Kjell-Magne Bondevik (Christian Democratic Party, PM 1997-2000, 2001-2005), Thorbjørn Jagland (Labour Party, PM 1996-97) and Jens Stoltenberg (Labour Party, PM 2000-2001, 2005-) reintroduced the male suit, now well-fitted but still low-key, as it should be in a conspicuously modest political context. However, there was some experimentation on Bondevik’s part. The former priest surprised many by on occasion wearing bright yellow suits in formal settings. Sometimes limits to experimentation are drawn even before they are surpassed: When Stoltenberg and his staff of young and ambitious men were called “Armani democrats, ${ }^{44}$ even though none of them wore Armani suits, this could be interpreted as a warning not to move too far away from a modest style.

The three last mentioned prime ministers have expressed their out-of-office interests through traditional leisure-time outfits, whether for hunting, football (soccer), mountain hiking, skiing, and bicycling, all sports with masculine or neutral connotations.

A major trend among Stoltenberg and his male fellow politicians is their positioning as dedicated family men. This caring attitude is not the care of a remote patriarch. It is rather a modern type of husband/father doing the various practical tasks of a family, and doing them as a most natural thing in the world--at the same time as they have top-level positions in politics. For many years Stoltenberg left important meetings in order to fetch his children from their child-care center. He says that he enjoys having a wife who is equal to him and holds her own views. Many of his male ministers state that there are limits to how much politics can require of them. The minister of foreign affairs, Jonas Gahr Støre, who generally comes out on top in surveys measuring people's confidence in politicians, has for many years alternated between "international top meetings and his children’s football teams.”45 According to Morgenbladet, these politicians represent a new political ideal for men: They

\footnotetext{
${ }^{44}$ E. Skarsbø Moen, Jens Stoltenberg (Oslo, 2002).

${ }^{45}$ Dagbladet, 23 November 2005.
} 
are warm, smart, self-confident, and often stylish. And they are deeply engaged with the destiny of the world--as well as with their families. ${ }^{46}$

This is a form of masculinity that underplays both power and sexuality. Admittedly, Stoltenberg has once challenged the solemn and modest political tradition by posing playfully and somewhat flirtatiously in a white shirt and dark trousers in a women's magazine. The caption for the picture was “A little Cary Grant. A little James Dean. And a little Jens Stoltenberg." ${ }^{47}$ But his charm is commonly regarded as "boyish” and "playful” rather than sexy; once he was called "a charmer who avoids power." ${ }^{48}$ His informal style and downplayed masculine charm does not put him in an elevated position, but in a symmetric, almost comradelike relation to his voters.

\section{[Picture 4 approx. here]}

\section{Discussion}

How can we sum up the general leadership styles of the French and Norwegian political leaders? And how can we go from mere description to the culturally coded patterns of visual and verbal depiction, and subsequently to the logic of national cultural repertoires?

The differences in general leadership styles in France and Norway are in line with the more general political ethos in each country, as described by various authors. While the politicians in France appear to be aloof, mystical, and seductive heroic leaders of the people, the politicians in Norway appear to be ordinary and modest, the people's servants.

Apart from the fact that uniforms and medals are only used in France, and mainly in the first three decades after the Second World War, the most striking fact in the cross-national comparison of male leaders is how similar they all look, at least at a superficial level. They are all using this conventional code of dress that suppresses individual expression and emphasizes the professional: the suit. This is not surprising when we take into account that the male suit has stayed more or less the same for the last 140 years. ${ }^{49}$ It has been generally accepted as a daily working costume in all white-collar professions in Western countries,

\footnotetext{
${ }^{46}$ Morgenbladet, 2-8 December 2005.

${ }^{47}$ Tara, 4 June 2005.

${ }^{48}$ Dagbladet, 27 December 2005.

${ }^{49}$ R. Rubinstein, Dress Codes (Oxford, UK, 2001).
} 
almost independent of fashions and trends. Wearing a suit appears the normal thing to do on the political stage. The illusion of neutrality makes it hard to criticize the performance. In fact, the man with the suit does not appear to be an actor at all. It is the politician who does not wear a suit--or who changes the suit's color or traditional accessories--that appears to pose and stage his performance. According to Collier, wearing a suit erases the sexed specificity of the individual male body. ${ }^{50}$ This does not render men desexualized. The sexuality is somehow put in the high formal position that the suit indicates, and not in the personal body which the suit covers.

Although the suit-wearing tradition in Norway and France makes the politicians look similar, there are also important differences. In both countries suits are read as signs of class and profession, but in Norway the lack of elegance--for example, suits made of inexpensive materials and not always fitting the man wearing it--for two or three decades after World War II could serve as a proud signs of not belonging to the higher classes, at least for the leaders on the left. That is why being called an "Armani democrat" may still be interpreted as an insult. The suits belonging to the Conservative leaders seem to be somewhat more stylish in the whole period. The reason for this difference might be that the Conservative leader usually wants to be identified with the class symbolism inherent in a suit--following Goffman, ${ }^{51}$ we could say that he embraces his political role by wearing a nice suit--while the socialist leader often signals what Goffman calls role distance from some part of the leadership role. An inelegant or poorly fitting suit becomes an effective way of demonstrating closeness and solidarity with the less fortunate.

Pettersen points out several ways of signalling embracement of or role distance from the suit for male representatives in the Norwegian Parliament. ${ }^{52}$ Unlike the "guardian of tradition," who embraces the suit, the "wearer" knows what is the standard dress code, the norm, but follows it in a more passive way. The "challenger" is still operating within the norm, but comments on it and thereby marks a distance from the role.

When Jørgen Kosmo, Norway’s former president of the Storting (Parliament), in 2002 reprimanded a representative of the Parliament for not being appropriately dressed, he acted as a gatekeeper, or "guardian of tradition”. Prime minister Jens Stoltenberg, however, can be seen as a passive wearer: "I have never been particularly fond of suits. They are

\footnotetext{
${ }^{50}$ R. Collier, “'Nutty Professors,' 'Men in Suits’ and 'New Entrepreneurs’: Corporeality, Subjectivity and Change in the Law School and Legal Practice,” Social \& Legal Studies 7, no. 1 (1998): 27-53.

${ }^{51}$ E. Goffman, The Presentation of Self in Everyday Life (Harmondsworth, UK, 1959).

${ }^{52}$ K. Pettersen, Dress med press: Et etnologisk blikk på mannlig klesbruk i stortingssalen (Oslo, 2004).
} 
fundamentally unpractical. However, they are easy to use.”53 The Norwegian politicians wearing poorly fitting or creased suits, but either don't care or regard this as proud signs of class, can be seen as challengers. Another example in our material is prime minister Kjell Magne Bondevik wearing bright yellow or red suits in formal situations. A more subtle challenge can be seen in the French prime minister Édouard Balladur's wearing of red socks with his formal black suits. The challenger marks individuality within the norm. Thus he opposes hegemonic dress codes without totally losing the respect of the traditional gatekeepers and the suit wearers, or from his own voters. The challenger helps us see what is the actual norm in formal political settings.

What then about politicians in informal settings? Chirac looks like he is wearing shiny dancing shoes and suit pants in the woods, and in this case it is the lack of informal leisure wear that is striking. Other French presidents, like Mitterrand and Sarkozy, use leisure wear that portrays them as relaxed or cool, but still superior. The cool and relaxed hero is a wellknown figure in Western culture and mythology, not least in Western film industry, and this image appears well suited for French presidents. We do not find a similar hero in Norway because being ordinary does not permit this kind of image. Norwegian politicians' leisure wear signals first of all manual work, farmwork, and sports. The role of the politician and the role of a humble farmer or a nature lover can effectively be merged without being criticized for being inauthentic, or staged. And in line with the ideal that emphasizes leaders as the people's servants, Willoch doing the dishes in his cottage and Stoltenberg fetching his children from child care centers and schools are not extraordinary images, although Willoch did challenge some gendered assumptions of leadership in the 1980s.

While personal appeal, which Weber claims is so central to charismatic authority, is coupled with heroic seductiveness in French politics, sexual references in the portrayal and description of Norwegian politicians are almost nonexistent. For example, the French press reports about the dynamic and passionate Jacques Chirac, “Mr. Testosterone” Dominique de Villepin, and the “decisive seducer” Nicolas Sarkozy. Admittedly, Norway also has a prime minister who is sometimes characterized as handsome and charming, but the lack of such characteristics is more profound than their presence. If such characterizations are employed, they are much more indirect. In Norway the expression "the power of character," which

\footnotetext{
${ }^{53}$ VG Helg, 14 March 2009.
} 
Tjeder $^{54}$ has suggested as a characteristic of Nordic mentality, deepens the telling expression Daloz $^{55}$ employs to describe the appearance of Norwegian politicians: conspicuous modesty.

Another difference that stands out in the comparison of the two countries is that visual appearance is more accentuated in France than in Norway. This is evident both in the way the politicians present themselves, and in the way and how often the press comments on the politicians' physical appearances. This is not surprising when we take into account the French aristocracy's emphasis on outward appearance. Elegance, fashion, and refinement are cherished qualities. ${ }^{56}$ Norway barely had any aristocracy, and to the degree there was one, its representatives were foreign rulers.

In addition to the factors already mentioned, institutional and political/ideological factors also play a part in explaining the differences between the two countries. That France is a republic while Norway is a monarchy might contribute to the heroic character of the president in opposition to the "ordinariness" of a prime minister. Nevertheless, the differences between the two countries are found at all levels in political life, not just at the top.

\section{Conclusions}

This article can be summarized in four points. First, it shows that the aesthetic of French politics is different from that of Norwegian politics, and that this difference can be attributed to differences in national cultural repertoires. In France political leadership is closely tied to heroism, grandeur, aloofness, and seduction. We see effortless superiority in many of the French leaders. The Norwegian puritanical tradition, which led to a concentration on inner character, together with a strong accentuation of equality stemming from the old peasant society, laid the ground for a more modest leadership ideal marked by closeness to the people-a conspicuous modesty.

Second, moving from general leadership ethos to the concrete appearance of male leaders, the article shows that French politicians are dressed to impress in elegant suits and formal clothes, and emotional and gallant gestures are part of the repertoire of effortless superiority. The French presidents seem to mark no distance from the black suit, rather it

\footnotetext{
${ }^{54}$ D. Tjeder, The Power of Character: Middle-Class Masculinities, 1800-1900 (Stockholm, 2003).

${ }^{55}$ J.-P. Daloz, "Ostentation in Comparative Perspective: Culture and Elite Legitimation," Comparative Social Research 21 (2003): 29-62.

${ }^{56}$ M. Lamont, Money, Morals and Manners: The Culture of the French and American Upper Middle Classes (Chicago: University of Chicago Press, 1992), 138.
} 
seems that they embrace the formal role that the suit symbolizes. The suit is just another sign of class and sophistication. Respect for bourgeois class culture is typical for France, ${ }^{57}$ but not for Norway. ${ }^{58}$ The comparatively less attention given to these things in Norway may be the reason why Norwegian politicians' suits appear more casual and artless, with less reference to style and fashion. The elegant and fashionable male politician is mainly found in France, and the modest and not so well dressed politician is only found in Norway. More specifically, our analysis of biographical and journalistic characterizations shows more challengers to the suitwearing norm in Norway than in France, and they seem to be using somewhat stronger means of protesting bourgeois class culture than the ones used by politicians in France. The analysis further shows that there are more challengers of classical norms of appearance on the left than on the right, but they are mainly in Norway. The pictures of French and Norwegian politicians in their spare time distinguish them even more than the more formal pictures do. We interpret this as a difference in national cultural repertoires.

Third, the analysis gives examples of how national cultural repertoires of evaluation change. The Norwegian leadership ethos of piety, moderation, and inward orientation is still important, but not as solemn and self-effacing as it used to be up until the 1970s. Compared to most leaders in French politics, however, who live up to a heroic leadership ideal marked by effortless superiority and seduction, the Norwegian leaders still look modest. French leadership styles have slowly changed as well. During the 1980s and 1990s it became clear that the French politicians not only had to be superior and presidential. They also had to prove that they were ordinary and close to the people. ${ }^{59}$ And even if Sarkozy seems to be relatively close to the people, his immodesty and explicitly expressed ambition also demonstrate a form of authority far from the matter-of-fact authority of many earlier presidents; his is superiority with effort, a leadership fought for. In this he represents something relatively new in French postwar politics.

Finally, the analysis gives examples of how national cultural repertoires of political leadership and power are gendered. De Gaulle’s military experience of battle constituted a defining element of his masculinity, the ultimate test of male self-confrontation, forming the male self-image along aggressive (and possibly virile) lines. This form of masculinity comes close to what Connell calls hegemonic masculinity. ${ }^{60}$ But we have also shown that forms of

\footnotetext{
${ }^{57}$ Ibid.

${ }^{58}$ A. Danielsen, ”Kulturell kapital i Norge. Om anvendelsen av Bourdieus begrep kulturell kapital,” Sosiologisk tidsskrift 6 (1998), 75-106.

${ }^{59}$ Drake and Gaffney, The Language of Leadership in Contemporary France, 23.

${ }^{60}$ Connell, Masculinities.
} 
masculinity clearly differ among French leaders, whether it is the seductive military heroic masculinity of de Gaulle, a culturally sophisticated, almost “tamed” masculinity (Pompidou and Giscard d'Estaing), a fatherly/avuncular and mature masculinity (Mitterand), a gallant masculinity (Chirac), or a tough, almost disruptive masculinity (Sarkozy). The Norwegian leaders mostly demonstrate other forms of masculinity. Admittedly, Gerhardsen's form of leadership has parallels to the fatherly masculinity of Mitterand, both being regarded as patriarchs. However, many of Gerhardsen's successors exerted a more symmetrical form of leadership: They were modest, solemn servants of the people. The most common expressions of gendered leadership in the last fifteen years have also been of a more symmetrical form. These days the Norwegian leaders are mostly regarded as smart, well-educated and familyoriented fathers (not patriarchs), comrades and friends. When Stoltenberg was reelected as prime minister in the fall of 2009, he was positively called "the brother of the nation." 61

\section{Acknowledgments}

We would like to thank Fredrik Engelstad, Wendy Griswold, Jean-Pascal Daloz, Håkon Larsen, and Phillip Smith for valuable comments on drafts of this article. In addition we would like to thank Aurélie Sylvie Viennet and Ellen Krag for their assistance with collecting data.

\footnotetext{
${ }^{61}$ Her og Nå, 15 September 2009.
} 


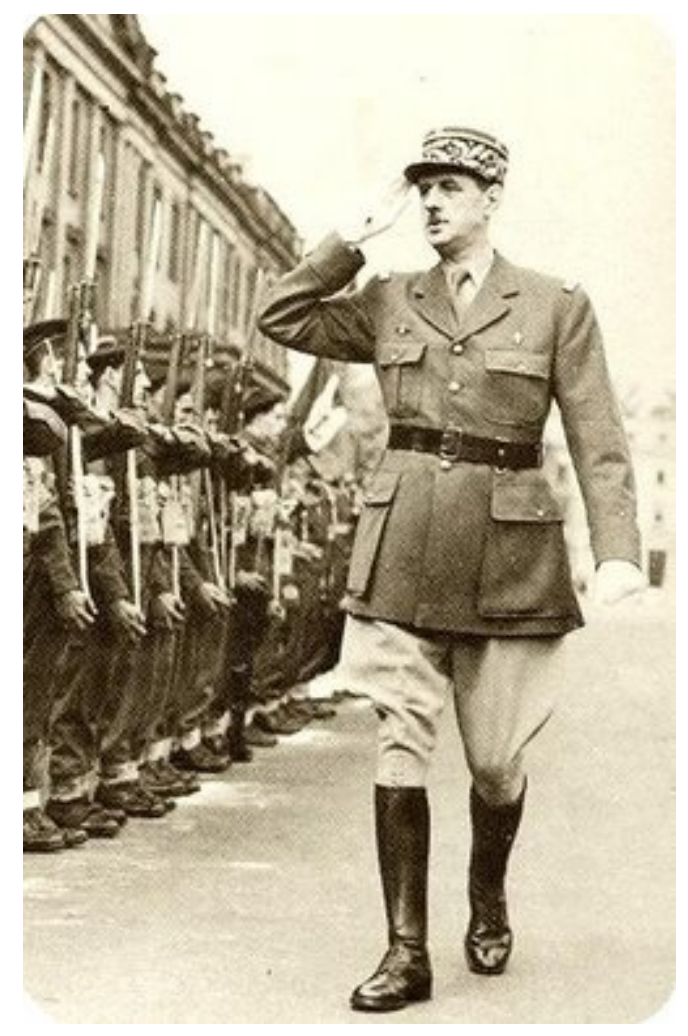

Picture 1. French General Charles de Gaulle, a war hero in a country imbued with the heritage of a Great Power tradition. ${ }^{62}$

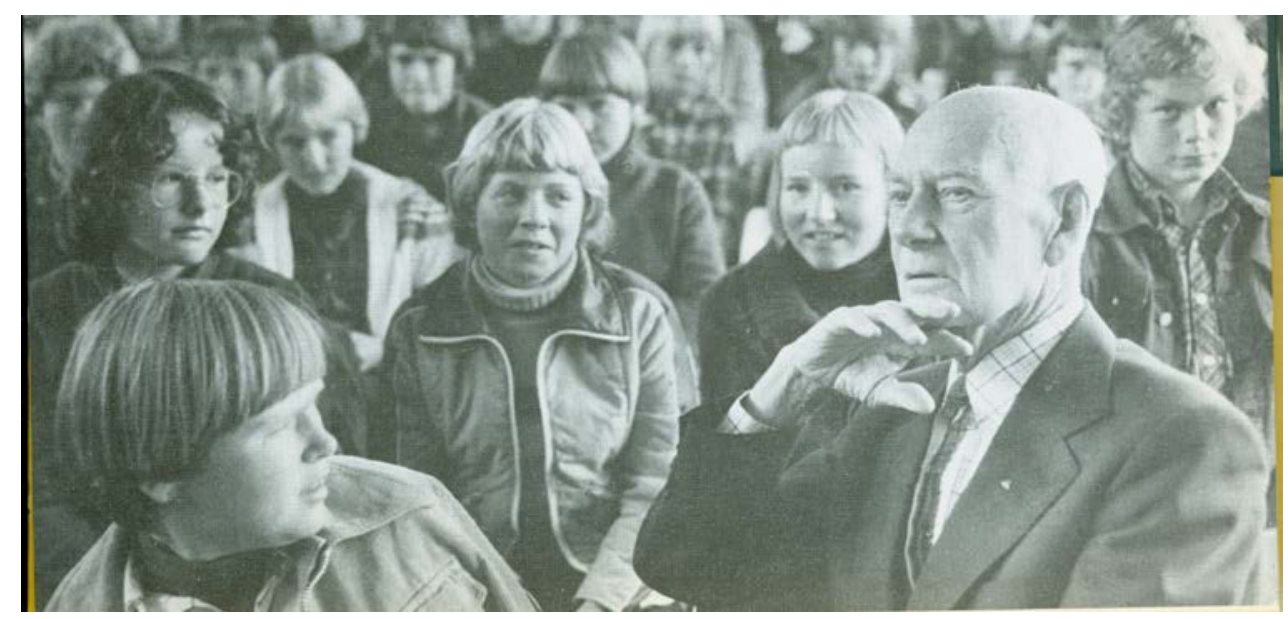

Picture 2. Prime Minister Einar Gerhardsen supports the image of Norway as strongly characterized by an ordinary people's power. ${ }^{63}$

\footnotetext{
${ }^{62}$ http://www.bonjourlafrance.net/france-facts/france-history/images/charles-de-gaulle-military.jpg

${ }^{63}$ E. Gerhardsen, Mennesker og politikk. Erindringer 1965-78 (Oslo, 1978), 220.
} 


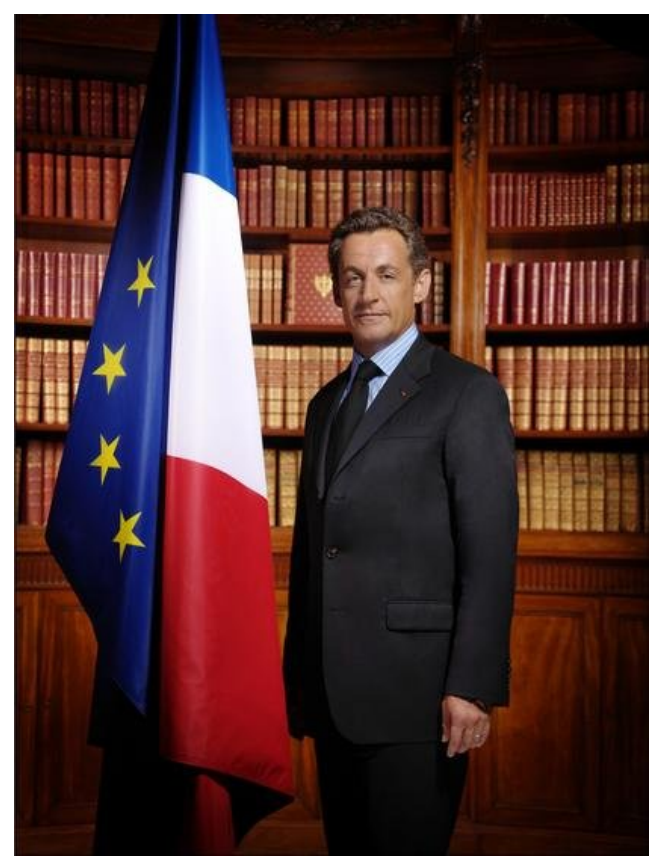

Picture 3. French President Nicolas Sarkozy's self-presentation on Facebook, 2009. A leadership image marked by traditional superiority. The picture, taken from below, adds to his heroic standing. ${ }^{64}$

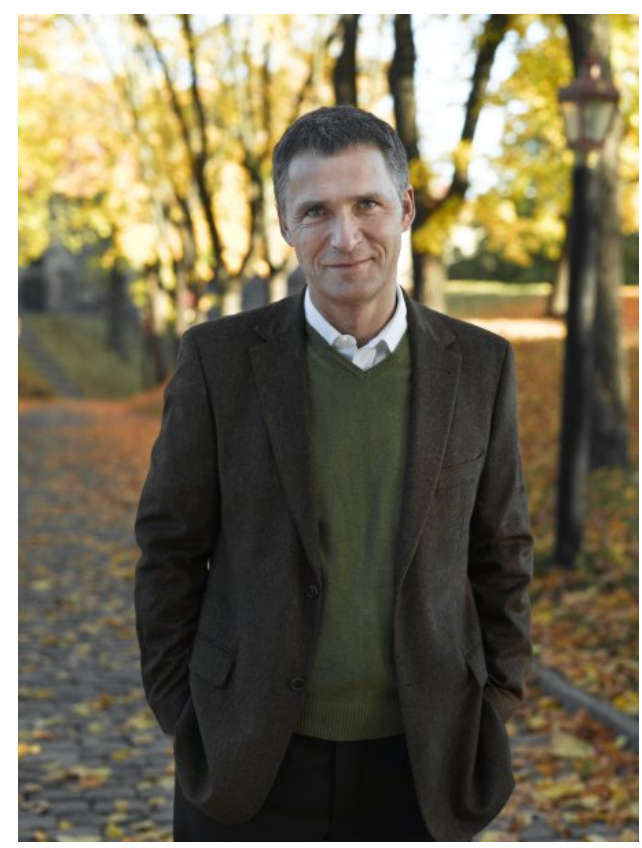

Picture 4. Norwegian PM Jens Stoltenberg's self-presentation on Facebook, 2009. A symmetric leadership image marked by informality and ordinariness. ${ }^{65}$

\footnotetext{
${ }^{64}$ http://www.facebook.com/photo.php?pid=2281997\&id=7766361077\#/photo.php?pid=573002\&id=776636107 7

${ }^{65}$ http://www.facebook.com/photo.php?pid=820510\&id=21646763580
} 